\title{
PENGABDIAN PURNA SANTRI DALAM MENINGKATKAN KEMAMPUAN MENGAJAR SANTRI PONDOK PESANTREN NURUL CHOLIL BANGKALAN
}

\author{
Abdullah', Mundiro Lailatul Muawaroh'2 \\ Universitas Darul Ulum Jombang, 2STIT Al-Ibrohimy Bangkalan
}

\begin{abstract}
Pada kenyataannya, tidak semua pendidik Begitu pula, tidak sedikit guru yang sering dituding bermasalah jika siswanya kurang berprestasi. Dengan diadakannya pengabdian purna santri (guru tugas) dalam iklim instruktif di pesantren, menjadi salah satu alternatif dalam melahirkan santri yang berkompeten dalam mengajar dan mendidik. Penelitian ini bertujuan untuk menganalisis pelaksanaan pengabdian purna santri dalam meningkatkan kemampuan mengajar santri Pondok Pesantren Nurul Cholil Bangkalan. Dalam penelitian ini, penulis menggunakan pendekatan studi kasus dan jenis penelitian kualitatif. Penelitian ini menemukan bahwa implementasi pengabdian purna santri pesantren Nurul Cholil Bangkalan bertujuan untuk membantu santri memiliki bekal, keterampilan dalam proses belajar mengajar di masyarakat. Selain itu, agar santri memiliki akhlak yang baik dan menjadi pendidik yang berakhlak mulia. Pesantren menjalin hubungan dengan masyarakat melalui program kerja wajib santri dalam upaya menyebarluaskan prinsip-prinsip Islam yang rahmatan lil alamin.

Kata Kunci: Pengabdian Purna Santri, Kemampuan Mengajar, Santri, Pesantren.
\end{abstract}

\section{ABSTRACT}

In educational practice, not all educators are able, aware and able to complete their obligations. Likewise, not a few teachers are often accused of having problems if their students are underachieving. With the holding of post-santri service (duty teacher) in an instructive climate at the pesantren, it becomes an alternative in giving birth to competent santri in teaching and educating. This study aims to analyze the implementation of post- santri service in improving the teaching ability of the santri of pesantren Nurul Cholil Islamic Bangkalan. In this research, the writer uses a case study approach and qualitative research type. This study found that the implementation of the postsantri service at pesantren Nurul Cholil Bangkalan aims to help the santri have the provision, skills, in the teaching and learning process in the community. In addition, so that the santri have good morals and become educators with noble character. The pesantren establish relationships with the community through compulsory santri work programs in an effort to disseminate Islamic principles that are rahmatan lil alamin.

Keywords: Post-santri Service, Teaching Ability, Santri, Pesantren.

\section{A. Pendahuluan}

Di era globalisasi, pendidik harus mampu memahami perbedaan peserta didik agar dapat memberikan pilihan kepada peserta didik dalam menghadapi masalah pembelajaran. Sehubungan dengan struktur tersebut, guru dituntut untuk dapat melakukan persiapan mengajar yang efektif dan efisien. Namun, ada sejumlah guru yang tidak melakukan persiapan atau RPP dengan berbagai alasan. Guru dapat dirugikan jika mengajar tanpa persiapan, karena profesional akan sangat mengganggu pertumbuhan peserta didik dan proses pembelajaran. ${ }^{1}$ Ilmu pengetahuan dan teknologi

1 E. Mulyasa, Menjadi Guru Profesional: Menciptaka Pembelajaran Kreatif dan Menyenangkan (Bandung: Remaja Rosda Karya, 2008), 21. 
telah berkembang sedemikian rupa sehingga dapat mempengaruhi perkembangan dan kecerdasan peserta didik, dan bakat tidak dapat diturunkan dari generasi ke generasi semata-mata melalui pengalaman hidup orang tua, tetapi harus dilakukan di bawah pengawasan orang yang memiliki kemampuan dan kerjasama dengannya guru. ${ }^{2}$

Di era globalisasi ini, untuk memajukan pendidikan setiap sekolah memutuhkan guru yang berintegritas, berwawasan luas dan ber keperibadian unggul, sehingga setiap peserta didik bisa meningkatkan kemampuan dengan proses pendidikan dan pembinaan dari guru. Karena anak pada usia tersebut masih tumbuh dan berkembang kepribadiannya, maka pengaruh kepribadian guru sangat penting bagi siswa usia sekolah. khususnya yang berada pada pendidikan dasar dan menengah. Guru harus senantiasa mengikuti Norma atau aturan yang mengikat yang disebut "etika" dalam kegiatan sehari-harinya, baik itu tentang Tuhan, sesamanya, lingkungan, atau dirinya sendiri ${ }^{3}$. Menurut William Lilie, "Ethics as the normative science of conduct of human being living in societies - a science which judges this conduct to be right orwrong, to be good or bad, or in some similar way"4

Etik adalah studi tentang perilaku manusia dalam masyarakat, dengan kemampuan untuk mempengaruhi perilaku yang benar atau salah, baik atau buruk, atau sesuatu yang serupa. Menjadi guru pertama membutuhkan profesionalisme, dan itu bukan pekerjaan yang bisa diserahkan kepada sembarang orang. ${ }^{5}$ Akibatnya, guru melakukan upaya sadar untuk mengerahkan tenaga dan pikiran dalam rangka mendidik siswa. Selanjutnya, karena proses pendidikan membentuk sikap dan perilaku siswa, maka peran dan fungsi guru dalam melaksanakan kegiatan belajar mengajar sangat penting dalam proses belajar mengajar. ${ }^{6}$

Guru diberikan derajat kehormatan dan kedudukan yang tinggi dalam Islam karena keutamaan guru yang agung dalam membimbing, mengarahkan, memberikan ilmu, menanamkan nilai-nilai, dan mempersiapkan siswa untuk masa depan dengan penuh keyakinan dan keyakinan. Dan dia diberi status sebagai hasilnya. ${ }^{7}$

\footnotetext{
2 Zakiah Darajat, Kepribadian Guru (Jakarta: Bulan Bintang, 1978), 7.

3 Etik menurut Syaiful Bahri Djamarah adalah tata susila (etika) atau hal-hal yang berhubungan dengan kesusilaan dalam mengerjakan suatu pekerjaan. Lihat dalam bukunya:"Guru dan Anak Didik Dalam Interaksi Edukatif" (Jakarta : Rineka Cipta, 2000), Cet. 1, 49.

4 William Lillie, An Introduction to Ethics (New York : Barnes and Noble, 1996), 1-2.

${ }^{5}$ Abuddin Nata, Perspektif Islam Tentang Pola Hubungan Guru dan Murid, (Jakarta: Raja Grafindo Persada, 2001), 1.

6 Fakultas Tarbiyah IAIN Walisongo, PBM-PAI Disekolah, Eksistensi dan Proses Belajar- Mengajar Pendidikan Agama Islam (Yogyakarta : Pustaka Pelajar, 1998), 179.

7 Abdullah \& Moh. Ismail, "Peran Ghuruh Tolang dalam Menanamkan Nilai Karakter pada Santri di Musholla alIsmail Tanah Merah Bangkalan”, EL-BANAT: Jurnal Pemikiran Dan Pendidikan Islam, Vol. 9, No. 2 (2019): 129155.
} 
Pengajar harus memiliki sifat zuhud; Menurut Mohammad Athiyah Al-Abrosyi, saifat yang dimiliki guru seharusnya mengharapkan keridhaan Allah semata, bukan mengutamakan keuntungan materi. Maka dari itu guru harus memiliki etika profesi. Guru bertanggung jawab untuk membimbing, mengawasi, memberikan tauladan, dan mendampingi siswa selama proses belajar mengajar. Guru harus mempertahankan sikap profesional dengan menunjukkan kompetensi mereka dan mendorong siswa untuk mencapai potensi penuh mereka. Guru harus memiliki pemahaman dasar tentang cara mengajar dan belajar. serta kepribadian yang hebat, profesionalisme, dan kapasitas untuk berhubungan dengan rekan kerja dan masyarakat.

Siswa wajib melakukan perjalanan ke pedesaan dan memasuki masyarakat sebagai bentuk pengabdian, sedangkan kegiatan pesantren berbentuk latihan studi madrasah. Formal, informal, atau non-formal adalah semua pilihan. Peran wajib pondok pesantren adalah meningkatkan kemampuan mengajar dan berhubungan secara profesional dengan masyarakat sesuai dengan tujuan pendidikan yang tertuang dalam Permendiknas Nomor 16 Tahun 2007 tentang Standar Kualifikasi Akademik dan Kualifikasi Guru. Khususnya, keterampilan pedagogik, kepribadian, profesional, dan sosial. $^{8}$

Guru memiliki peran penting dalam memastikan bahwa proses belajar mengajar berhasil. Mengingat proses belajar sangat penting dan juga tidak kalah pentingnya adalah keberadaan guru, maka dari kualitas guru harus diperhatikan. ${ }^{9}$ Menurut Shaleh Abdul Azis dan Abdul Azis Abdul Majid: ${ }^{10}$

"Bahwasannya belajar itu adalah perubahan di dalam hati (tingkah laku) anak atau peserta didik yang timbul atas pengalaman yang lalu sehingga timbul perubahan baru, Perbuatan lebih jelas (kuat pengaruhnya) dari pada perkataan".

Ungkapan di atas memiliki pengertian bahwa peserta didik menirukan sikap dan tindakan gurunya serta mengutip pernyataan pernyataannya. Guru sebagai fasilitator serta memberikan suritauladan bagi peserta didik seperti memotivasi, disiplin, perilaku yang baik, prestasi dan keinginan belajar peserta didik. Guru merupakan bagian penting dari keberhasilan proses pembelajaran, dan keterlibatan mereka dalam proses belajar mengajar memotivasi siswa untuk berpartisipasi dalam proses pembelajaran di kelas. Globalisasi telah mengantarkan era baru pada tuntutan masyarakat teknologi modern dibutuhkan proses belajar-mengajar yang efektif, sehingga proses

\footnotetext{
8 Pedoman PPL Fak.Tarbiyah dan Keguruan UIN SunanAmpel Surabaya, 2016.

${ }^{9}$ Mulyasa, Menjadi Guru Profesional: Menciptakan Pelajaran Kreatif dan Menyenangkan, 5

10 Shaleh Abdul Azis dan Abdul Azis Abdul Majid, At-Tarbiyatu Wa Turuku At-Tadris ( Mesir: Darul Ma'arif, t, th), 169.
} 
pembelajaran menyenangkan, semangat peserta didik dan menjadi masyarakat terdidik. ${ }^{11}$

Guru memainkan peran penting dalam mengembangkan pendidikan dan menentukan efektivitas proses pendidikan. Akibatnya, segala inovasi dan pengembangan pendidikan yang terkait dengan rencana pendidikan, serta peningkatan sumber daya manusia, harus berasal dari pendidik. Hal ini menunjukkan bagaimana tugas pendidik di bidang pendidikan dilaksanakan. Seorang pendidik yang dekat harus dapat melaksanakan kesepakatan pada tingkat dasar. Salah satu keterampilan tersebut adalah kemampuan pendidik itu sendiri, yang meliputi: 1) kemampuan dan kombinasi individu, 2) kepekaan terhadap perubahan dan informasi, 3) penalaran yang disukai, 4) disiplin yang dapat diterima, sah, dan disengaja, dan 5) dalam penyelesaian pekerjaan 6) konsisten dan kerja keras, 7) keinginan untuk mendapatkan hasil terbaik, 8) cerdas dan menarik, adaptif, dan esensial dalam kehidupan sehari-hari, 9) terbuka, 10) inventif, dan definitif. ${ }^{12}$

Calon guru perlu untuk menguasai materi, selain itu juga dalam teknik, media, dan pemahaman isu-isu dalam sistem pembelajaran, seperti isu-isu inspirasional, kontras dalam atribut siswa, dan kapasitas mereka untuk menangkap materi. Dari afektabilitas ini, wajar jika pengajar sebenarnya ingin menyampaikan dengan tepat dan efektif akan menghasilkan komunikasi ruang belajar yang ideal. Sebagaimana dinyatakan dalam sasaran Pendidikan Nasional, pada umumnya Pendidikan Nasional dikoordinasikan untuk menyelidiki dan membina SDM yang idealnya bertekad untuk menyiapkan masa depan negara untuk menghadapi kesulitan dunia, demi tercapainya menciptakan pendidik yang cakap yang secara konsisten menjadi inspirasi dalam mengajar. terlebih lagi, sistem pembelajarannya dengan memberikan hasutan. Selain itu, mendukung dan dapat menggerakkan kemampuan siswa dalam membina latihan psikologisnya, sehingga terjadi dinamika dalam ukuran pendidikan dan pembelajaran.

Pada kenyataannya, tidak semua pengajar mampu dan sadar serta menyelesaikan kewajiban dan kewajibannya. Tidak sedikit guru yang sering dituding jika sekolah dan sifat siswanya kurang berprestasi dan tidak memenuhi kebutuhan masyarakat. Terlepas dari manfaat dan hambatannya, pendidik merupakan jalan menuju pencapaian persekolahan seperti halnya SDM yang berkualitas, beriman dan

\footnotetext{
${ }^{11}$ Makmun Abin Syamsudin, Psikologi Kependidikan : Perangkat System Pengajaran Modul (Bandung : PT. Remaja Rosdakarya, 2007), 17.

${ }^{12}$ Cece Wijaya \& Tabrani Rusyan, Kemampuan Dasar Guru Dalam Proses Belajar Mengajar (Bandung : Remaja Rosdakarya, 1992), 13.
} 
bertaqwa. Dengan diadakannya pengabdian purna santri (Guru Tugas) dalam iklim instruktif di pesantren, maka akan melahirkan santri yang berkompeten. Pelaksanaan pengabdian purna santri dalam pesantren berpengaruh terhadap peningkatkan kemampuan mengajar serta dalam pengabdian purna santri dapat dijadikan founding father sebagai pedoman bagi santri-santrinya dan masyarakat.

Dengan deskripsi tersebut, jelas bahwa pengabdian purna santri mempunyai pengaruh terhadap kematangan santri. Maka dari itu, kajian tentang pengabdian purna santri dalam meningkatkan kemampuan mengajar memiliki perbedaan dengan PPL yang ada di perguruan tinggi pada umumnya.

\section{B. Urgensi Pengabdian Purna Santri}

Pengabdian purna santri adalah tindakan skolastik melalui praktik pembelajaran di sekolah atau madrasah. Pengabdian purna santri adalah pemanfaatan semua materi yang diperoleh santri selama belajar di pesantren. Ada beberapa istilah yang digunakan untuk mencirikan pengabdian santri seperti menunjukkan praktek praktek pengalaman lapangan atau disebut juga komitmen santri senior terhadap organisasi-organisasi instruktif yang telah ditentukan dari pondok pesantren. Usaha wajib tersebut pada dasarnya adalah melakukan/memberikan cara belajar sebagai informasi, etika yang baik dan lain-lain. ${ }^{13}$

Sudah sewajarnya santri yang telah menyelesaikan sistem pembelajaran atau pendidik akan menjadi pengajar yang cakap dan memiliki ketaqwaan yang tinggi dalam menunaikan kewajibannya dengan baik. Latihan melalui peragaan latihan yang dilakukan oleh seseorang secara terarah untuk mengamankan Salah satu syarat menyelesaikan program ini adalah kemampuan untuk memberi contoh dan diambil dala kerangka waktu tertentu. ${ }^{14}$ Berdasarkan informasi yang disajikan di sini, masuk akal untuk mengasumsikan bahwa tugas wajib adalah: Pertama, dilaksanakan secara terbimbing. Pengabdian purna santri atau kewajiban santri yang diperlukan diselesaikan oleh seseorang di ruang belajar

\footnotetext{
13 Neneng Rika Jazilatul Kholidah, “Analisis Kemampuan Mengajar pada Pelaksanaan PPL”, Jurnal Ilmiah Edukasi \& Sosial, Volume 8, Nomor 1, (Maret 2017). Lihat pula di Novy Eurika, "Kemampuan Praktik Mengajar Mahasiswa PPL Prodi Pendidikan Biologi Unmuh Jember”, Jurnal Biologi dan Pembelajaran Biologi, Volume 1 Nomor 2 (2016).

${ }^{14}$ Abdul Kadir Munsyi, dkk, Pedoman Mengajar ( Surabaya : Usaha Nasional, 2001), 20.
} 
dan daerah setempat. Santri berprestasi yang bersekolah di sekolah pendidik seperti PPL, PGA, dan sekolah pendidik lainnya yang harus menyelesaikan latihan mengajar sering melakukannya. Adapun yang dimaksud dengan pembinaan dalam pengabdian setelah santri menyelesaikan proses belajar. Praktik mengajar calon guru dibimbing oleh seorang wali atau orang yang bertugas membantu guru dari sekolah tempat mereka melaksanakan tugas praktik mengajar. Penanggung jawab asisten guru ini selalu memberikan arahan, nasehat, nasehat kepada peserta didik tentang tugas-tugas mengenai segala sesuatu yang ada hubungannya dengan pengajaran dan sosial masyarakat. ${ }^{15}$ Karena santri wajib tugas tidak hanya mengajar saja, akan tetapi bisa belajar berintraksi langsung dengan masyarakat.

Kedua, prakter dalam mengajar. Pelaksanaan pengabdian purna santri merupakan bagian dari proses belajar, mempraktekkan materi yang dipelajari selama di pesantren. Santri yang melaksanakan tugas wajib harus benar-benar memiliki karakter dan sikap seorang guru. Karena, dalam hal dia memberi contoh di depan santri dan daerah maka kapasitasnya benar-benar sebagai pengajar. Selanjutnya, ingat bahwa seorang pendidik, selain memberikan ilmu dan memberikan contoh positif bagi anak-anak dan masyarakat. Karena latihan pertunjukan ini adalah suatu kegiatan, itu harus memiliki jangka waktu tertentu. Khususnya dalam latihan peragaan, seorang pendidik yang akan datang melakukan tindakan peragaan beberapa kali (tergantung standar yang diterapkan). Karena semakin sering tindakan mengajar, semakin baik dan berbakat seorang pendidik dalam menyelesaikan panggilan mendidiknya.

Ketiga, bertujuan untuk lebih mengembangkan kemampuan mengajar. Salah satu kapasitas dan tujuan dari kewajiban yang diperlukan adalah untuk memperoleh kemampuan mendidik. Kemampuan tidak muncul begitu saja; itu harus dikembangkan melalui latihan dan kemampuan. Selain serius juga tak henti-hentinya dalam melakukan tindakan mendidik itu sendiri. ${ }^{16}$ Bagi santri yang melakukan tugas-tugas yang diperlukan, secara keseluruhan latihan yang

\footnotetext{
15 Ibid., 21.

16 Neneng Rika Jazilatul Kholidah, “Analisis Kemampuan Mengajar pada Pelaksanaan PPL', Jurnal Ilmiah Edukasi \& Sosial, Volume 8, Nomor 1, (Maret 2017).
} 
mereka lakukan adalah untuk memenuhi tugas menyelesaikan program pembelajaran. Untuk santri, sebelum meninggalkan sekolah langsung, Tugas yang terkait dengan program pengalaman lapangan harus diselesaikan. Karena bisnis merupakan salah satu kegiatan yang dapat diikuti oleh mahasantri saat mereka berkunjung dan keluar daerah setempat. Dalam menyelesaikan latihan peragaan, pendidik yang akan datang harus kreatif dalam mengajar, hal ini setiap kali diikuti akan mendapatkan gambaran tentang contoh hubungan antara pengajar, Santri dan konten (atau materi pembelajaran). Setiap pendidik memiliki desain pengajaran mereka sendiri. Desain pertunjukan ini tercermin dalam perilaku ketika menyelesaikan pendidikan seperti di pesantren. Dengan istilah " Teaching style atau gaya mengajar", guru menanamkan pola perilaku mengajar yang luas. Gaya mengajar ini mewakili bagaimana pendidik melakukan pelajarannya, yang dipengaruhi oleh filosofi mengajar guru itu sendiri, ide-ide psikologis yang digunakan, dan kurikulum yang digunakan. ${ }^{17}$ Dalam latihan pertunjukan nyata, pendidik yang akan datang diharapkan untuk mendapatkan banyak perhatian tentang panggilan dan parade menjadi seorang pendidik baik dalam hal pengajaran maupun kegiatan pengajaran lainnya. Sehingga cenderung dianggap bahwa kewajiban wajib bagi mahasantri senior di yayasan pendidikan sangat bermanfaat dalam menyelesaikan tugas-tugas pendidikan dan dapat mengkoordinir mahasantri sebagai calon pendidik yang cakap.

1. Unsur-Unsur Pengabdian purna santri

Jika kita menyelidiki dari atas ke bawah, bahwa dalam ukuran pengajaran dan pembelajaran yang merupakan pusat dari ukuran pelatihan yang tepat di sekolah, ada hubungan antara komponen yang berbeda. Komponen ini meliputi: ${ }^{18}$

a. Subyek mengajar atau guru

Sederhananya, guru adalah orang yang mengajar siswa. Guru, dalam pandangan masyarakat, adalah orang yang mengajar pengajaran di berbagai tempat, termasuk masjid, masjid, rumah tangga, dan situs lainnya, di samping lembaga pendidikan formal. ${ }^{19}$ Pendidik adalah pusat dari proses belajar

\footnotetext{
17 Muhammad Ali, Guru Dalam Proses Belajar Mengajar (Bandung : Sinar Baru Algensindo, 1996), 5.

18 Bambang Septiawan, "Pola Penerapan Sistem 'ngabdi' yang Dilakukan Pondok Pesantren Bahrul Maghfiroh Malang dalam Konteks Manajemen Sumber Daya Manusia”, Jurnal Ilmu-Ilmu Ekonomi, Volume 13 Nomor 2 (2020).

19 Syaiful Bahri , Guru dan Anak Didik Dalam Interaksi Edukatif (Jakarta : Rineka Cipta, 2000), 31.
} 
mengajar, dan tanggung jawab guru adalah untuk melacak segala sesuatu yang terjadi di kelas untuk membantu proses pembelajaran. Jelas, tanggung jawab guru adalah untuk menjaga perhatian peserta didik: ${ }^{20}$ 1) Memberikan arahan dan dorongan kepada peserta didik untuk membantu mereka mencapai tujuan jangka pendek dan jangka Panjang; 2) Menyediakan pertemuan pembelajaran yang cukup sebagai sarana pencapaian tujuan; 3) Membantu dalam peningkatan mentalitas, kualitas, dan perubahan individu. Akibatnya, dalam proses belajar mengajar, pendidik bertanggung jawab lebih dari sekedar mentransfer informasi; ia juga bertanggung jawab atas keseluruhan pengembangan karakter santri. ia harus memiliki pilihan untuk melakukan interaksi belajar sehingga bahwa hal itu dapat mendorong santri untuk beradaptasi secara efektif dan kuat dalam memenuhi kebutuhan mereka. mereka. terlebih lagi, pencapaian objektif.

b. Peserta didik atau objek mengajar

Seorang pembelajar dapat digunakan sebagai alat pengajaran. Peserta didik mewakili potensi kelas, yang harus dimanfaatkan oleh guru untuk mencapai proses belajar mengajar yang efektif. Peserta didik adalah generasi muda yang berkembang jasmani dan rohaninya untuk mencapai tujuan pendidikannya melalui lembaga pendidikan formal, khususnya sekolah. ${ }^{21}$ Peserta didik memiliki rasa memiliki yang kuat sebagai elemen kelas, yang sangat penting untuk menghasilkan pengaturan kelas yang dinamis. Setiap siswa harus merasa diterima oleh teman sekelasnya agar dapat berpartisipasi dalam kegiatan kelas. Penerimaan ini akan membentuk sikap tanggung jawab terhadap kelas, yang akan berdampak langsung pada pertumbuhan dan evolusi satu sama lain. Karena anak-anak adalah orang yang potensial, guru harus menginspirasi dan membimbing mereka. Ketika siswa menjadi komponen penting dari proses pembelajaran, mereka merupakan masalah serius dalam kemitraan pembelajaran.

Peserta didik sebagai makhluk manusia, memiliki karakteristik sebagai berikut: 1) Siswa belum memiliki karakter yang matang secara sosial sehingga masih menjadi kewajiban pengajar (pendidik); 2) Siswa mempelajari bagianbagian tertentu dari perkembangan yang ideal, sehingga masih menjadi

\footnotetext{
${ }^{20}$ Slameto, Belajar dan Faktor-Faktor yang Mempengaruhinya (Jakarta : Rineka Cipta, 1995), 97.

${ }^{21}$ Rika Devianti,Suci Lia Sari, “Urgensi Analisis Kebutuhan Peserta Didik Terhadap Proses Pembelajaran”, Jurnal Al-Aulia Volume 06 No 01 Januari-Juni 2020
} 
kewajiban guru; 3) Peserta didik memiliki ciri-ciri dasar manusia yang tumbuh secara terkoordinasi, termasuk biologis, sosial, pengetahuan, emosional, ucapan, bagian tubuh untuk mengoperasikan (kaki, tangan, jari), dasar alami atau latar belakang sosial (warna kulit, bentuk tubuh), dan lain-lain. Dan ada perbedaan antara orang-orang. ${ }^{22}$

2. Tujuan pengabdian purna santri

Dalam penggambaran sebelumnya telah diperjelas bahwa tugas wajib santri adalah suatu bentuk gerakan melalui pertunjukan praktek yang dilakukan oleh seseorang secara terarah untuk memperoleh kemampuan dalam memberi contoh dan diambil sebagai salah satu prasyarat untuk menyelesaikan suatu program tepat waktu. Alasan mendasar wajibnya program administrasi santri atau pendidik itu sendiri adalah agar santri-siswi yang mengajar secara jujur dapat mandiri dan menyesuaikan diri dengan daerah setempat. Sehingga realitasnya dapat bermanfaat bagi daerah setempat. Tujuan kewajiban yang disyaratkan antara lain: ${ }^{23}$

a. Mengasah keahlian mengajar.

Yang dimaksud dengan keahlian di sini adalah ketersediaan dan kapasitas individu untuk menyelesaikan kewajibannya dengan baik dan efektif, selain dari kemampuannya untuk mendominasi masalah yang akan diteruskan kepada orang lain. Kemampuan datang, namun harus melalui pengembangan pengembangan dan kapasitas mereka sendiri. ${ }^{24}$ Mendidik, khususnya, membutuhkan berbagai bakat, seperti terlihat pada gambaran di atas, lebih spesifiknya: Pertama, membuka dan menutup pelajaran. Untuk membangun suasana 'siap mental' dan membuat peserta didik memusatkan perhatian pada apa yang akan diwujudkan, pendidik harus memiliki bahan yang tepat untuk membuka pelajaran, terutama kegiatan guru di awal presentasi. ${ }^{25}$ Dalam hal ini, seorang pendidik harus memberikan pengenalan dan arahan dengan mata pelajaran yang akan diajarkan kepada peserta didik sehingga mereka siap dan tertarik untuk mengikuti pembelajaran. Namun, dalam mengajar, pembukaan dilakukan tidak hanya di awal, tetapi juga setiap kali Anda melanjutkan ke poin lain dengan mengungkapkan tujuan yang ingin Anda capai, mendapatkan perhatian peserta didik, dan menghubungkan antara mata pelajaran yang telah dikuasai. Ada juga

\footnotetext{
22 Hadari Nawawi, Organisasi Sekolah dan Pengelolaannya Kelas ( Jakarta: CV Haji Masagung, 1989), 127.

23 Neneng Rika Jazilatul Kholidah, "Analisis Kemampuan Mengajar pada Pelaksanaan PPL", Jurnal Ilmiah Edukasi \& Sosial, Volume 8, Nomor 1, (Maret 2017).

${ }^{24}$ Munsyi, dkk, Pedoman Mengajar, 39.

${ }^{25}$ Ginarso, Suseno TW, Program Pengalaman Lapangan I (Yogyakarta : Andi Offset, 1986), 25.
} 
tema segar untuk dipikirkan. Perilaku guru dalam menyelesaikan sesi dengan menyampaikan aspek-aspek penting tertentu dalam pembelajaran ditunjukkan dengan menutup pelajaran. Upaya seorang guru untuk memberikan gambaran menyeluruh tentang apa yang telah diajarkan adalah menutup pelajaran, dan mengetahui keberhasilan belajar santri juga dapat membantu menentukan apa yang akan mereka pelajari selanjutnya. ${ }^{26}$

Kedua, Kapasitas untuk menjelaskan. Pendidik harus mampu mendidik, misalnya, dengan secara efektif menyajikan informasi yang dirancang secara lisan untuk menunjukkan korelasi antar variabel, seperti kondisi dan hasil yang losgis, definisi, atau sesuatu yang tidak jelas atau tidak diketahui. ${ }^{27}$ Ketiga, kemampuan pertanyaan. Kemampuan untuk mengajukan pertanyaan adalah kegiatan dalam kerangka bantuan dengan meningkatkan kemampuan berpikir santri dan menambah data. Keempat, keterampilan penguatan. Pembelajaran adalah segala bentuk respon, verbal dan non-verbal yang penting bagi seorang pengajar untuk melakukan perubahan sesuai dengan perilaku santri yang berarti memberikan informasi atau analisis kepada peserta didik tentang latihan mereka sebagai tindakan dorongan atau perbaikan. Kelima, keterampilan variasi Variasi peningkatan adalah praktik gerakan guru pendidik berkenaan dengan sarana pengajaran dan asosiasi pembelajaran yang direncanakan untuk menghilangkan kelelahan peserta didik, sehingga dalam keadaan belajar dan belajar santri selalu bersemangat, dan penuh energik.

b. Berkontribusi dan mengembangkan ilmunya sesuai dengan profesi

Seorang pendidik harus memahami suatu sifat agar dapat memperlancar penerapan pendidikan. Kegagalan seorang guru untuk menciptakan lingkungan kelas yang sesuai disebabkan oleh kurangnya pemahaman pendidik tentang kepribadian siswa Akibatnya, guru harus terlebih dahulu memahami keadaan siswa sebelum mengembangkan tahapan kontak instruksional.

\section{E. Pengabdian Purna Santri dan Pemahaman Keagamaan Masyarakat}

Pondok pesantren telah mewarnai wilayah Indonesia dengan tumbuh di tengah peradaban sebagai lembaga pendidikan dan penginjilan, serta lembaga sosial. Akibatnya, pesantren ini tidak hanya dapat diterima secara kultural,

\footnotetext{
26 Ibid., 27.

27 Suseno TW Ginarso, Program Pengalaman Lapangan I, 81. 
tetapi juga telah memberikan pola nilai bagi kehidupan masyarakat yang selalu berkembang dan berkembang. Peran pesantren sebagai mekanisme reformasi budaya yang lengkap dalam masyarakat adalah latar belakang yang paling signifikan. ${ }^{28}$ Semuanya dibayangi oleh pesatnya kemajuan teknologi dan ilmu pengetahuan. Sebagian besar remaja menghabiskan banyak waktu di media sosial, menghindari praktik keagamaan seperti berdoa bersama dan berpartisipasi dalam kegiatan yang dapat membantu mereka tumbuh secara spiritual.

Pesantren merupakan salah satu solusi masyarakat atas kesulitan mereka. Pemecahan atas kesulitan-kesulitan dewasa ini, khususnya dalam hal perilaku keagamaan remaja, dapat ditemukan dengan kembali kepada hukum yang benar, khususnya Al-Qur'an dan hadits. Selain berpaling kepada Al-Qur'an dan As-Sunnah sebagai pedoman dalam menghadapi kesulitan, pesantren yang berkembang pesat saat ini melakukan upaya yang sungguh-sungguh dan mengambil langkah-langkah nyata untuk meningkatkan perilaku keagamaan kaum muda. ${ }^{29}$ Pengiriman guru pendamping ke lembaga pendidikan di masyarakat terpencil salah satunya, seperti menyelenggarakan safari Ramadhan untuk memberikan pembelajaran dan penyuluhan kepada masyarakat.

Adanya tugas guru dari Pondok Pesantren Nurul Cholil dalam membina pemahaman keagamaan masyarakat khususnya pemuda luar biasa, baik dalam agama, akhlak maupun amalan keagamaan dalam kehidupan sehari-hari, perilaku remaja telah mengalami perubahan yang positif. ${ }^{30}$ Santri Nurul Cholil yang ditugaskan di beberapa lembaga ini memiliki dampak baik dalam membina umat beragama khususnya remaja, banyak anak-anak yang biasanya malas mengaji, suka nongkrong di gardu-gardu, semenjak ada guru yang bertugas sekarang sudah mulai ke Mosolla, mungkin pendekatan yang dilakukan oleh guru tugas itu baik, makanya banyak anak yang tertarik dan mulai ingin terus mengaji. 31

\footnotetext{
${ }^{28}$ Zamakhsyari Dhofier, Tradisi Pesantren: Studi tentang Pandangan Hidup Kyai (Jakarta: LP3ES, 200 ), 16.

29 Amir Mahmud \& Zaini Tamin AR, "Transformasi Pesantren (Studi terhadap Dialektika Kurikulum dan Kelembagaan Pondok Pesantren Rifaiyah Pati)", EL-BANAT: Jurnal Pemikiran dan Pendidikan Islam, Vo. 9 No.2 (2019): 156-176.

30 Hambali, Wawancara, Bangkalan, 15 Agustus 2020.

31 Syokron, Wawancara, Bangkalan, 16 Agustus 2020
} 
Pendidikan agama yang diberikan kepada masyarakat, khususnya yang masih berusia belasan tahun, cukup bermanfaat. Pembinaan berupa kegiatan seperti mengadakan final menjelang akhir tahun ajaran, dimana masyarakat setempat, khususnya remaja, berpartisipasi dalam kegiatan tersebut untuk mengelola atau mengisi acara. Hal ini merupakan bukti upaya tulus Pondok Pesantren untuk meningkatkan keragaman masyarakat dengan mendelegasikan peran guru. Santri tugas mampu berkomunikasi dengan baik dengan remaja sehingga dapat mengajak remaja untuk berperan aktif dalam berbagai kegiatan keagamaan, Selain memperingati hari besar Islam yang kaya akan tilawah, seperti peringatan Isra' Mi'raj, halal bi halal, Maulid Nabi Muhammad SAW. Derajat keakraban antara santri pondok pesantren dengan remaja di lingkungan sekitar kemungkinan akan semakin meningkat seiring dengan diperingatinya hari besar Islam ini. Antara kedua belah pihak terjalin komunikasi yang baik. Secara tidak langsung, pembinaan keagamaan pemuda di Desa Delamba dapat berjalan dengan lancar bagi masyarakat melalui berbagai kegiatan seperti ini. ${ }^{32}$

Agar keberadaan Pondok Pesantren Nurul Cholil dapat dirasakan oleh masyarakat dengan adanya para santri yang ditugaskan untuk mengajar. Para santri yang ditugas telah berusaha memberikan pelayanan untuk memenuhi kebutuhan keagamaan masyarakat sekitar. Program kegiatan Pondok Pesantren adalah memberikan pembinaan kepada masyarakat dalam rangka mengembangkan akhlak dan perilaku beragama dengan melibatkan masyarakat khususnya remaja, baik dalam bidang pendidikan maupun keagamaan, dengan tujuan untuk meningkatkan pengalaman keagamaan di masyarakat. Akibatnya, perjalanan keagamaan masyarakat bertumpu pada ilmu yang dipelajari. 33

Berdasarkan hasil penelitian, Pondok Pesantren Nurul Cholil memiki peran sebagai fasilitator. Dimana keberadannya dapat menjadi sarana untuk menambah pengalaman keagamaan masyarakat sekitar dan juga memiliki peran sebagai agen pembangunan. Diharapkan keberadaan Pondok Pesantren Nurul Cholil dapat menjadi control sosial bagi umat beragama. Biasanya, pesantren menggabungkan kaum muda dalam acara-acara hari raya keagamaan, yang

\footnotetext{
32 Moh Syakir, Wawancara, Bangkalan, 16 Agustus 2020.

${ }^{33}$ Moh Syakir, Wawancara, Bangkalan, 19 Agustus 2020. 
menciptakan lingkungan yang akrab bagi para pemuda dan santri di sekitarnya, memungkinkan mereka untuk bertukar informasi yang bermanfaat pada kesempatan tertentu. Pesanten, sebagai agen keunggulan, berfungsi sebagai forum pertukaran tidak hanya pengetahuan agama tetapi juga ilmu pengetahuan umum. Oleh karena itu, Pondok Pesantren Nurul Cholil ingin memperluas penawaran pendidikannya. Pesantren Nurul Cholil mendelegasikan tugas merancang metode pembelajaran yang dikenal sebagai studi diniyah kepada santrinya. Pengetahuan pesantren yang meningkat seringkali memberikan kesan bahwa sistem di pesantren itu unik. Aspek-aspek yang menguntungkan ini harus lebih ditingkatkan. Penilaian ini mengakui bahwa dunia pesantren berperan penting dalam pembangunan pendidikan nasional.

Ibadah, upacara keagamaan formal, ketaatan, dan tindakan yang dilakukan seseorang untuk menunjukkan komitmen terhadap agamanya adalah contoh praktik keagamaan. Banyak orang khususnya remaja kurang memperhatikan ajaran agama seperti waktu sholat, karena disibukkan dengan hal lain, sehingga ketika tiba waktu sholat iqomah masih banyak orang atau anak muda yang belum siap untuk sholat berjemaah. Beberapa orang pergi ke masjid untuk sholat berjamaah, sementara yang lain tidak. Keragaman komunitas pemuda, khususnya dalam kegiatan berjamaah, kurang intens. Meski hanya terjadi setiap lima tahun sekali, namun tetap ramai, dan masjid ini umumnya dipadati jamaah remaja saat salat Maghrib. Karena berbagai masalah, banyak remaja di wilayah tersebut yang tidak tertarik dengan kegiatan masjid. Kurangnya keragaman agama di kalangan anak muda sebagian besar disebabkan oleh orang tua mereka. Minimnya keragaman agama di kalangan anak muda di daerah tersebut antara lain disebabkan oleh keadaan ekonomi penduduk yang didominasi oleh kelas menengah ke bawah. Orang tua yang disibukkan dengan pekerjaan memiliki efek tidak langsung pada anak-anaknya. ${ }^{34}$

Banyak dilatarbelakangi oleh para remaja yang kurang memperhatikan ajaran agama terutama bagi santri yang kurang memperhatikan waktu sholat karena sibuk dengan berbagai alasan, oleh karena itu banyak santri yang masih

\footnotetext{
${ }^{34}$ Syaiful, Wawancara, Bangkalan, 20 Agustus 2020.
} 
belum siap untuk hadir ke masjid pada waktu iqomah. Bahkan terkadang ada yang tidak ikut berjamaah sholat. Ada banyak fakto yang mempengaruhi banyak pemuda disekitar tidak tertarik dengan kegiatan di masjid, orang tua menjadi factor utama sedikitnya keberagamaan agama pada kalangan pemuda, Lingkungan ekonomi menengah ke bawah juga menjadi katalisator dari tidak adanya religiusitas di kalangan anak-anak di sekitarnya, dengan orang tua yang terlalu disibukkan dengan pekerjaan mereka berdampak pada anak-anak mereka secara tidak langsung. Beberapa keadaan tersebut menyebabkan banyak anak muda yang lebih fokus dengan kegiatan ekonomi memenuhi kebutuhan jasmani tanpa mempertimbangkan kebutuhan rohani saat ini.

Kondisi ekonomi masyarakat tidak bisa menjadi alas an untuk saling menyalahkan, karena pada dasarnya kebutuhan ekonomi adalah kebutuhan pokok setip manusia, sedangkan religiutas juga menjadi hak setiap manusia, hal tersebut menyebabkan tokoh masyarakat tidak bisa menuntut keberagamaan dikalangan pemuda. Karena berdampingan dengan Pondok Pesantren, mereka berpandangan bahwa yang terpenting adalah mengandalkan generasi muda dengan terus melakukan hal-hal atau kegiatan yang positif. Laki-laki muda yang tidak patuh dalam menjalankan cita-cita agama masih terlihat dalam berbagai upacara di kalangan anak muda., ada baiknya jika para pemuda mengamalkan ajaran agama dalam kesehariannya agar agama dapat secara bertahap menjadi pengikat atau bahkan dapat untuk melaksanakan shalat wajib tepat waktu dan tidak menunda-nunda.

Pendekatan yang dilakukan oleh ustadz bersama tokoh masyarakat kepada orang tua merupakan upaya membina kemajemukan pemuda karena keluarga menjadi factor utama dalam membentuk kepribadian anak, juga dalam perkembangan agama pada anak. Oleh sebab itu, pondok pesantren dan tokoh masyarakart memberi sarana dalam pengembagan keberagamaan anak, dengan melalui program pembelajaran Al-Quran di Mushala yang kini sedikit demi sedikit mulai ditinggalkan. Para orang tua yang memiliki anak putra maupun putri pada usia sekolah disarankan untuk mengikuti program tersebut, sehingga pada usia dini pembinaan keagamaan pada pemuda bisa ditanamkan. 


\section{Pengabdian Purna Santri dalam Meningkatkan Kemampuan Mengajar}

Manusia memerlukan pendidikan karena pendidikan sangat berpengaruh terhadap sikap dan tindakan setiap orang menuju kehidupan yang lebih baik, terutama dalam hal kemajuan dan perkembangan. Karena siklus instruktif akan mengembangkan sudut pandang intelektual, spiritual, dan psikomotorik, setiap individu akan secara mandiri dapat memposisikan dirinya. sebagai individu, entitas sosial, dan makhluk moral

Allah SWT menganjurkan kepada hambanya untuk selalu mencari ilmu dan menularkannya kepada sesama karena ilmu akan melindungi manusia dari keterbelakangan dan ilmu juga dapat membedakan manusia, Allah berfirman dalam al-Qur'an surat at-Taubat, ayat 122.

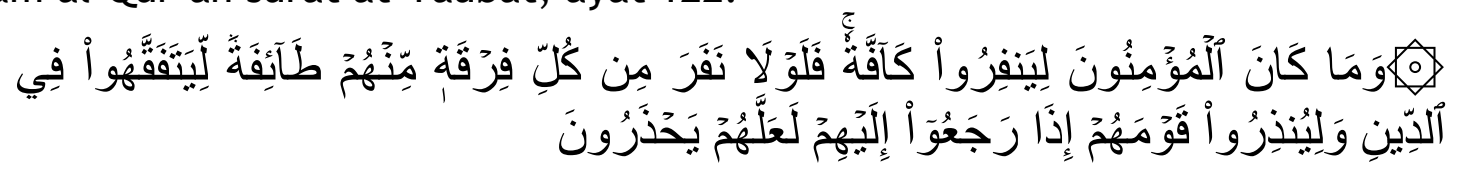

“Tidak sepatutnya bagi mukminin itu pergi semuanya (ke medan perang). mengapa tidak pergi dari tiap-tiap golongan di antara mereka beberapa orang untuk memperdalam pengetahuan mereka tentang agama dan untuk memberi peringatan kepada kaumnya apabila mereka telah kembali kepadanya, supaya mereka itu dapat menjaga dirinya". (QS At-Taubat, ayat 122). ${ }^{35}$

Selain pengaturan keluarga dan kelompok, sekolah adalah salah satu dari tiga pusat pendidikan. Sekolah memainkan peran penting dalam pendidikan anak-anak karena mengandung langkah-langkah pengajaran dan pembelajaran yang menghasilkan hubungan yang informatif antara guru dan murid. Pendidik sangat penting dalam pendidikan karena gurulah yang menentukan tercapai atau tidaknya tujuan pendidikan. Pelatihan yang berkualitas akan diberikan oleh pendidik yang berkualitas, dan hasil yang berkualitas akan dihasilkan oleh sekolah yang menyeluruh.

Profesi guru merupakan pekerjaan ahli yang memiliki konsekuensi dalam tugas dan juga tanggungjawabnya, baik sebagai peserta didik sebagai administrator kelas maupun sebagai pengawas kelas, yang kesemuanya merupakan tugas pokok para pengajar. Tanggung jawab dan kewajiban ini secara eksplisit terkait dengan kemampuan yang diperlukan untuk mempertimbangkan mengajar sebagai panggilan. Karena dengan fokus pada

35 Departemen RI, Al-Qur'an Tajwid dan Terjemahannya (Bandung: Jabal Raudhotul Jannah,2009), 206. 
prasyarat saat ini, para pengajar diharapkan memiliki pilihan untuk menerapkan kemampuan dan keterampilan yang telah mereka peroleh untuk memiliki pilihan untuk mengarahkan santri mereka. Salah satu syarat untuk menjadi seorang guru adalah berlatih mengajar, atau mendidik, atau yang dikenal dengan empat sertivikat. Karena mengikuti program praktik mengajar akan membekali Anda dengan pengetahuan tentang kemampuan dan pengetahuan yang berkaitan dengan praktik belajar mengajar.

Penguasaan santri sebagai kader sivitas akademika atau ulama dapat terlaksana dengan baik seperti yang diprediksikan dengan mengikuti program tugas wajib jika penanggung jawab telah melakukannya dengan sukses, terencana, terarah, dan konsisten. Tahap yang akan menambah atau menawarkan hasil untuk pendidik adalah pengabdian wajib untuk tugas ini., pada dasarnya memiliki pilihan untuk menyelesaikan dan membuat langkahlangkah pengajaran dan pembelajaran sehingga tujuan pertunjukan dapat dicapai dengan tepat, layak dan efektif.

Mendidik adalah aktualisasi pengetahuan teoritis dalam tindakan mengajar dan belajar. Pendidik harus memiliki dan menguasai kemampuan untuk menunjukkannya. untuk melengkapi ukuran pengajaran dan pembelajaran yang edukatif, berdaya dan cakap. Kemampuan ini akan meningkat seiring dengan bertambahnya pengalaman setiap pendidik. Kapasitas yang dibutuhkan seorang pendidik adalah kemampuan untuk mengawasi pelaksanaan pendidikan dan pembelajaran dengan baik, mulai dari membuat pengaturan yang merupakan proporsi dari prestasi pendidik dalam pelatihan serta memberikan kenyamanan kepada pendidik dan memutuskan sarana dalam mengajar. Guru akan ingin melakukan latihan mengajar yang melibatkan bakat khusus dari seorang pendidik jika lingkungan diatur dengan cermat. Karena mengajar lebih dari sekedar memberikan pengetahuan kepada santri.Setiap pendidik memiliki karakter dan kapasitas alternatif. Perbedaan ini mengharapkan para pendidik untuk memiliki pilihan untuk membangun hubungan yang baik dengan santri di dalam dan di luar ruang belajar dengan cara yang edukatif.

Guru harus secara konsisten belajar dan menumbuhkan pemahaman logis karena mendidik tidak dapat dipisahkan dari belajar. Kemajuan yang pesat dan 
masyarakat yang berkembang menuntut setiap pendidik untuk menumbuhkan wawasan yang luas dan terus-menerus menambah setiap orang yang bersangkutan. Karena pendidiklah yang mengendalikan seluruh ukuran pembelajaran. Kemajuan ilmu pengetahuan dan inovasi juga telah mendorong peningkatan alam semesta pengajaran. Guru diharapkan untuk berpikir secara umum untuk saat ini, dan tetap berpegang pada kerangka kerja dan taktik usang yang kurang produktif dan efisien. Pelatihan tidak hanya memperoleh karakteristik dan efek dari budaya kuno, tetapi juga mempersiapkan generasi muda untuk menerima situasi saat ini dan di kemudian hari. ${ }^{36}$

Setiap keterampilan tidak dilahirkan dengan sendirinya karena kemampuan ini diperoleh melalui proses pendidikan dan pengajaran yang berkelanjutan. Tugas mengajar dipandang sebagai sesuatu yang sederhana oleh orang-orang tertentu, termasuk menunjukkan panggilan yang masih diremehkan. Meskipun demikian, dengan sekolah akan membawa individu pada perkembangan, Dianggap tugas pendidik adalah tugas yang paling berat dan paling mulia, karena mereka akan berguna dan siap untuk hidup dengan baik secara mandiri, bermasyarakat dan beretika.

Praktek mengajar terkait erat dengan kemampuan mengajar. Frekuensi praktik pengajaran yang diikuti oleh masing-masing guru sangat mempengaruhi kemampuan mengajarnya. Dianggap tugas pendidik adalah tugas yang paling berat dan paling mulia, karena mereka akan berguna dan siap untuk hidup dengan baik secara mandiri, bermasyarakat dan beretika.

Pelaksanaan administrasi pasca-sarjana diandalkan untuk dapat menunjukkan santri dan membuat kerangka pengajaran yang sesuai dengan apa yang telah diatur baru-baru ini. Dengan administrasi pasca-mahasantri (tugas yang diperlukan untuk mahasantri), kapasitas pertunjukan mereka akan meningkat. Persiapan yang serius memberi, kemampuan pertunjukan tambahan akan meningkat. Selanjutnya, ketika kinerja guru meningkat, maka akan bekerja pada sifat hasil belajar santri dan mencapai target yang telah ditentukan.

\footnotetext{
${ }^{36}$ Nana Syaodih Sukmadinata, Pengembangan Kurikulum : Teori dan Praktek (Bandung : Remaja Rosdakarya, 2001), 58
} 
Pondok Pesantren Nurul Cholil Demangan Barat Bangkalan Madura putra bertugas melaksanakan ikrar Pondok Pesantren Nurul Cholil Demangan Barat Bangkalan Madura. Dididik baik di pondok pesantren maupun di lembaga pendidikan plosoks desa. Nurul Cholil terkenal karena pendekatannya yang ketat terhadap pendidikan. Hal ini dilakukan agar setelah berada di pesantren, santri akan mandiri. Paling tidak, Anda bisa berkontribusi pada masyarakat.

Hal ini menjadi pemikiran serius sekaligus menjadi salah satu program Pengasuh Pondok Pesantren Nurul Cholil Demangan Bangkalan Madura Barat, tahun ini Pondok Pesantren Nurul Cholil Bangkalan Barat, Madura yang dikelola KH Zubair Muntashor telah mengirimkan ratusan santri ke beberapa daerah di Indonesia. Para santri terpilih yang diputuskan memiliki pengetahuan yang memadai diberi mandat sebagai guru tugas di berbagai madrasah yang sedang membutuhkan. Hal ini juga menjadi syarat bagi santri untuk meninggalkan pesantren.

Santri yang bertugas diangkat atas permintaan pimpinan madrasah, yang kebetulan bersahabat dengan pesantren. Program ini sudah berlangsung cukup lama. Tujuannya tidak hanya untuk membantu sekolah madrasah pedesaan yang membutuhkan guru yang ditugaskan, tetapi juga santri yang ingin belajar dan mengembangkan wawasan di masyarakat. Program pengabdian atau penugasan guru itu sendiri hanya berjangka waktu tiga tahun, dan tujuan utama dari program atau penugasan tersebut adalah untuk mendidik mahasantri pascasarjana. Mandiri dan mampu beradaptasi dengan masyarakat. Agar keberadaannya dapat bermanfaat bagi masyarakat. Santri paling tidak terlihat di acara slametan, acara tahlilan, dan pernikahan.. ${ }^{37}$

Proses pembelajaran santri dimulai pada pukul 07.00-12.00 dan diisi dengan pelajaran agama di Amsilati. Pesantren Nurul Cholil dalam membekali santri dengan berbagai ilmu, baik ilmu agama maupun ilmu umum, proses pembelajaran santri dimulai pada pukul 07.00-12.00 dan diisi dengan pelajaran agama di Amsilati, madrasah diniyah Ula dan Wustha sedangkan ulya dimulai jam 19-.21, 30. Setelah itu, dari pukul 13.30 hingga 17.00 para santri mengikuti

\footnotetext{
${ }^{37}$ Masduki, Wawancara, Bangkalan, 15 Agustus 2020.
} 
pelajaran sekolah umum, Madrasah Tsanawiyah dan Aliyah. Pukul 17.00 santri berangkat ke musholla utama untuk mempersiapkan sholat magrib, santri mengulang hafalannya, baik itu hafalan alfiah, alquran maupun penghafalan kitab-kitab lainnya. Usai salat Maghrib, para santri mengikuti kegiatan sesuai jenjangnya. Ada tartilul quran, kajian kitab. Setelah salat isyak hingga pukul 21.30, seluruh santri mengikuti kegiatan musyawarah.” 38

Kegiatan dan Pelajaran Pelajaran penting lainnya yang harus diikuti oleh santri di hari libur Jumat adalah ceremah dan qiroatul qur'an. Kegiatan ekstrakurikuler ini memberikan santri dengan pengetahuan tambahan yang memungkinkan mereka untuk berpartisipasi dalam acara keagamaan dan sosial. Banyak santri di Nurul Cholil berasal dari tempat selain Madura, antara lain Surabaya, Jakarta, Lumajang, bahkan Pontianak. Dari ibtida' I yang berlangsung selama enam tahun, hingga tsanawiyah yang berlangsung selama tiga tahun, aliyah yang berlangsung selama tiga tahun, bahkan paket kejar-kejaran, program dan setting dikelompokkan dengan baik dari satu level ke level berikutnya. Partisipasi musyawarah antar pondok (bahsul masa'il) juga sering diikuti. Pelayanan pasca kemahasantrian bagi lulusan tiga tsanawiyah yang tidak melanjutkan ke jenjang aliyah atau mahasantri yang lulus aliyah.

Dari proses pendidikan di pesantren, banyak lulusan pesantren Nurul Cholil yang menjadi orang-orang sukses, baik itu pemuka agama, kepala desa, wiraswasta dan sebagainya. Pesantren Nurul Cholil telah memelihara keutamaan salaf dan tasawuf di hati seluruh santri yang berpegang teguh pada ajaran Allah dan Rasul-Nya hingga saat ini. Nilai-nilai salaf pondok ini teguh dan menakutkan di zaman modernisasi dan kemajuan. Sejak awal hingga saat ini, semua pengasuh secara berkesinambungan menanamkan prinsip-prinsip salaf di seluruh santri.

Antusiasme para pengasuh, dewan keluarga dan pengurus untuk terus memajukan pesantren sangat besar. Untuk mencapai tujuan akhir, diselenggarakan berbagai program, baik teoritis maupun praktis, baik secara individu maupun kolektif. Pembelajaran yang dilakukan di pondok pesantren

38 Khusairy, Wawancara, Bangkalan, 15 Agustus 2020. 
dilakukan selama hampir 24 jam bagi santri, bertujuan untuk menghasilkan santri yang berkualitas, berakhlak mulia dan memberikan bekal ketika kembali ke masyarakat, menjadi manusia yang dapat memberikan manfaat bagi masyarakat. Pengaruh pengabdian purna santri (wajib tugas santri) dari pesantren setelah lulus bisa membuat relasi antara pesantren dengan masyarakat dan pesantren memiliki peran penting dalam membina umat beragama. Perkembangan tatanan moral dan agama yang berkembang sebagai hasil dari pengalaman dan Orang tua menanamkan nilai-nilai moral dalam kehidupan anak-anaknya sejak usia dini. yang dievaluasi dan diarahkan oleh orang tua. Agama sangat penting dalam perkembangan moral karena moralitas berasal dari agama dan tidak berubah dengan waktu atau tempat.

Dalam kegiataan keagamaan, para remaja umumnya dipengaruhi oleh teman-temannya. Anak-anak muda yang sering keluar dari masyarakat dan apatis terhadap agama biasanya terbawa oleh perlakuan dan cara pandang daerah setempat yang tidak memberikan posisi yang tegas, sehingga hal tersebut sering kali mempertajam konflik-konflik pada remaja. Sikap dan tindakan mana yang menyebabkan kelompok tersebut bertentangan dengan nilai-nilai masyarakat, dan tidak jarang agama dan lembaga keagamaan menjadi sasarannya; jika lembaga keagamaan dapat menyelesaikan masalah sekaligus memberikan penghargaan kepada masyarakat, sehingga pemuda dapat aktif dan bekerja keras di bidang agama.

\section{F. Kesimpulan}

Pelaksanaan pengabdian purna santri di Pondok Pesanten Nurul Cholil Demangan Barat Bangkalan Madura bertujuan untuk membantu para santri supaya memiliki mengetahui dan keterampilan dalam proses belajar mengajar dan berintraksi dengan masyarakat secara langsung. Para santri di didik dan dibekali ilmu pengetahuan agar dapat menjadi seorang ulama, pendakwah, seorang pendidik yang berpekeperibadian unggul juga professional. Tugas wajib para santri dilaksanakan setelah para santri yang lulus tsnawiyah tidak melanjutkan ke Aliyah (ingin boyong). Dan bagi santri yang melanjutkan jenjang aliyah juga sama di wajibkan tugas setelah dinyatan lulus, sedangkan tempat 
sudah di tentukan oleh pengasuh. Program tugas wajib santri merupakan relasi antara pesantren dengan masyarakat serta pesantren hadir untuk memenuhi kebutuahn masyarakat tentang bimbingan dan pembinaan.

\section{G. Referensi}

Abdullah, A., \& Ismail, M. "Peran Ghuruh Tolang dalam Menanamkan Nilai Karakter pada Santri di Musholla al-Ismail Tanah Merah Bangkalan". EL-BANAT: Jurnal Pemikiran Dan Pendidikan Islam, Vol. 9 No. 2 (2019): 129-155.

Ali, Muhammad. Guru Dalam Proses Belajar Mengajar, Bandung : Sinar Baru Algensindo, 1996.

Azis, Shaleh Abdul dan Majid, Abdul Azis Abdul. At-Tarbiyatu Wa Turuku At-Tadris, Mesir: Darul Ma'arif, t, th.

Darajat, Zakiah. Kepribadian Guru. Jakarta: Bulan Bintang, 1978.

Departemen RI, Al-Qur'an Tajwid dan Terjemahannya. Bandung: Jabal Raudhotul Jannah,2009.

Devianti, Rika \& Sari, Suci Lia. "Urgensi Analisis Kebutuhan Peserta Didik Terhadap Proses Pembelajaran”. Jurnal Al-Aulia Volume 06 (2020).

Dhofier, Zamahsyari. Tradisi Pesantren: Studi tentang Pandangan Hidup Kyai. Jakarta: LP3ES, 2001.

Djamarah, Syaiful Bahri. Guru dan Anak Didik Dalam Interaksi Edukatif. Jakarta : Rineka Cipta, 2000.

Eurika, Novy. "Kemampuan Praktik Mengajar Mahasiswa PPL Prodi Pendidikan Biologi Unmuh Jember”. Jurnal Biologi dan Pembelajaran Biologi Volume 1 Nomor 2 (2016).

Fakultas Tarbiyah IAIN Walisongo. PBM-PAl Disekolah, Eksistensi dan Proses BelajarMengajar Pendidikan Agama Islam. Yogyakarta : Pustaka Pelajar, 1998.

Ginarso, Suseno TW. Program Pengalaman Lapangan I. Yogyakarta : Andi Offset, 1986.

Kholidah, Neneng Rika Jazilatul. "Analisis Kemampuan Mengajar pada Pelaksanaan PPL”. Jurnal Ilmiah Edukasi \& Sosial, Volume 8, Nomor 1 (2017).

Lillie, William. An Introduction to Ethics. New York : Barnes and Noble, 1996.

Mahmud, Amir., \& AR, Zaini Tamin. "Transformasi Pesantren (Studi terhadap Dialektika Kurikulum dan Kelembagaan Pondok Pesantren Rifaiyah Pati)". EL-BANAT: Jurnal Pemikiran dan Pendidikan Islam, Vo. 9 No.2 (2019): 156-176.

Mulyasa, E. Menjadi Guru Profesional: Menciptaka Pembelajaran Kreatif dan Menyenangkan. Bandung: Remaja Rosda Karya, 2008.

Munsyi, Abdul Kadir dkk, Pedoman Mengajar, Surabaya : Usaha Nasional, 2001. 
Nata, Abuddin. Perspektif Islam Tentang Pola Hubungan Guru dan Murid. Jakarta: Raja Grafindo Persada, 2001.

Nawawi, Hadari, Organisasi Sekolah dan Pengelolaannya Kelas. Jakarta: CV Haji Masagung, 1989.

Pedoman PPL Fak. Tarbiyah dan Keguruan UIN SunanAmpel Surabaya. 2016.

Slameto. Belajar dan Faktor-Faktor yang Mempengaruhinya. Jakarta : Rineka Cipta, 1995.

Sukmadinata, Nana Syaodih. Pengembangan Kurikulum : Teori dan Praktek. Bandung : Remaja Rosdakarya, 2001.

Syamsudin, Makmun Abin. Psikologi Kependidikan : Perangkat System Pengajaran Modul. Bandung : PT. Remaja Rosdakarya, 2007.

Wijaya, Cece., \& Rusyan, Tabrani. Kemampuan Dasar Guru Dalam Proses Belajar Mengajar. Bandung : Remaja Rosdakarya, 1992.

\section{Hasil Wawancara}

Masduki, Wawancara, Bangkalan, 15 Agustus 2020.

Khusairy, Wawancara, Bangkalan 15 Agustus 2020.

Hambali, Wawancara, Bangkalan, 15 Agustus 2020.

Syukron, Wawancara, Bangkalan, 16 Agustus 2020.

Moh syakir, Wawancara, Bangkalan, 16 Agustus 2020.

Musadad, Wawancara, Bangkalan, 29 Juli 2020.

Syaiful, Wawancara, Bangkalan, 20 Agustus 2020. 